\title{
Governments' Perspective on Engaging Citizens in the Co-Creation of E-Government Services: A Meta-Synthesis of Qualitative Case Studies
}

\author{
Anupriya Khan ${ }^{1}$, Satish Krishnan ${ }^{1, *}$ and A.K.M. Najmul Islam² \\ ${ }^{1}$ Indian Institute of Management Kozhikode, India \\ \{anupriyak09fpm, satishk\} @iimk.ac.in \\ ${ }^{2}$ University of Turku, Finland \\ najmul.islameutu.fi
}

\begin{abstract}
The innovative and improved delivery of public services is largely contingent on the co-creation process. Noting that engaging citizens in the development and delivery of e-government services is challenging and that limited attention is given to the process of facilitating citizen participation, this study intends to explore (a) governments' perception of the co-creation; and (b) how governments can facilitate citizen participation in the development of egovernment services. Through a meta-synthesis of qualitative case studies, this study identifies factors that are crucial for enabling co-creation, and develops a process view of the co-creation of e-government services to provide a holistic understanding on how the process of co-creation can be facilitated by the government and how the citizens could be engaged. The study thus contributes to the literature on e-government and public administration by improving the understanding of co-creation phenomenon, and suggests the mechanisms to improve citizen participation for the benefit of practitioners and policy makers.
\end{abstract}

Keywords: Co-creation, Citizen Participation, Open Innovation, E-government Service, Meta-synthesis, Qualitative Case Study.

\section{Introduction}

Enid Mumford [1] admitted that work systems function towards enhancing human experience when the interests, needs, and values of different stakeholders are well integrated (p. 20). She held a strong belief in favor of the use of computers and information systems in all areas to enhance the quality of human life. E-government is a remarkable example of such information system. Governments across many countries are now investing effort and significant amount of money to develop e-government systems to deliver and improve public services [3].

\footnotetext{
${ }^{*}$ Corresponding author.
} 
Mumford also endorsed the participatory approach to the design and development of computer-based work systems [1]. A participatory design approach not only enables users to impart their skills and knowledge but also renders an opportunity for learning and knowledge sharing for the benefit of both designers and users. It further empowers users by creating a sense of ownership within them and encourages acceptance of new systems [2]. The participatory approach involves interaction between stakeholders that allows system developers to gain understanding on the diverse objectives, needs, and characteristics of various groups, which, in turn, help in defining and validating requirement specifications [3]. Apparently, it bestows several benefits on stakeholders working towards the design and improvement of products, systems, and services. For instance, the participatory approach can better match the individual's needs with the services provided, and enhance the usability, reliability, and security of the systems [3].

Similar thought is observed to be echoed in the concept of co-creation. Since its inception in service management and marketing literature [4], the concept of cocreation is widely been adopted and studied in the fields of public administration and e-government [5-6]. Despite that the new studies are being emerged on co-creation, there is a substantial lack of consensus on its definition. This is largely due to its close association with the vast field of public administration [7] that produces research in several directions with difference in theoretical positions. For the purpose of this study, we describe co-creation as the "involvement of outside, non-typical, stakeholders in the initiation, design, implementation, and/or evaluation of a public service" [8]. Governments around the world are allegedly beginning to try out or implement cocreation practices in the development of public services [7]. The co-creation may increase government transparency, generate innovative and efficient public services, solve social problems and challenges, and help connect citizens and the government to provide higher levels of public value $[4,9]$.

The motivation for co-creation often is linked to its potency of generating higher levels of public value. The concept of "public value" is highly debated and discussed in the literature, yet there is no widely agreed upon definition of it [7]. However, in general, public value can be considered to be created at a societal level. In other words, "it is something that emerges when people use or create something" [7, p. 89]. It is worthy to note that public service delivery is rapidly changing; it is growing as more open and collaborative, and less top-down driven. This generates a new paradigm where new technologies, such as e-government and open government, empower stakeholders to create new services that are meaningful and valuable to them. Nevertheless, the current research suggests that citizens are hardly involved in cocreation of public services. Their direct participation appears to be almost non-existent [10] [12]. In most cases, the e-government development is followed through a technocentric approach, instead of participatory approach [3]. Therefore, it becomes imperative to gain understanding of how to facilitate the co-creation process for enabling an effective and efficient public service delivery.

The government is believed to play a crucial role in engaging citizens in the process of the co-creation of e-government services [13]. Governments may perceive their citizens as consumers or as participants. Such perception would largely decide the actions the government would take towards co-creation. Accordingly, to enhance our understanding of co-creation, specifically the process of engaging citizens in cocreation, there is a need to explore (1) what governments perceive about co-creation; 
and (2) how they facilitate the citizen participation. Although prior studies have analyzed and consolidated the benefits of co-creation by reviewing the literature, little is known about the process of facilitating the citizen participation in the co-creation of e-government services. Hence, in an attempt to develop an in-depth understanding of the co-creation from governments' perspective, we conducted a meta-synthesis of 10 qualitative case studies. A meta-synthesis refers to "an exploratory, inductive research design to synthesize primary qualitative case studies for the purpose of making contributions beyond those achieved in the original studies" [14, p. 523]. The metasynthesis can offer a holistic understanding of a phenomenon, reveal important insights, and help build a theory. Analyzing the selected studies by the meta-synthesis approach, we propose a process view of the co-creation that entails how the process of co-creation can be facilitated by the government and how the citizens could be engaged. We, therefore, contribute to the literature on e-government and public administration by improving the understanding of the process of co-creation, and suggest the mechanisms to facilitate citizen participation for the benefit of practitioners and policy makers.

\section{Background}

\subsection{Co-Creation}

With the development of the new forms of public service delivery, specifically the cocreation of public service, the understanding of public value is appeared to be shifting. Though the concept of "public value" is applied and discussed in many studies, there is hardly a consensus as to what this term actually entails. The study by Bryson et al. [15] provides a thorough overview of the different predominant views on public value. Amongst those, the most commonly held view is given by Mark Moore, who believes that "the task of a public sector manager is to create public value" [17], and managers would be able to create public value by aligning different factors in a "strategic triangle" [16]. Stoker [18] suggests another notion of public value. He supports the idea of networks, and contends that public value can be delivered by interacting and engaging with stakeholders [18]. He also argues that the created "public value" could change over time [18]. These examples indicate how the understanding of public value has been shifted. Now, researchers have started arguing that public value is not something which is static; instead, it can be developed at societal level from some service or activity [7]. This is further supported by Ostrom [19], one of the distinguished authors dealing with public value, who noted that public value can emerge through a process of co-production. Osborne [20] also acknowledged that public services can be created by any actor, and public value can be generated through interactions between service user and service provider [4].

Another phenomenon that nearly resembles the concepts of public value and coproduction is the concept of co-creation [7]. Alike public value, co-creation is also conceptualized in the literature in different ways. We contend that the essence of cocreation is deemed to rest upon the concept of open innovation. Being stemmed from the private sector, open innovation aims to enlarge the knowledge base by involving outsiders into decision making; sharing skills and expertise with outsiders; and 
innovating thorough a collaborative approach [22-23]. Participation and engagement are fundamental while exploring the philosophical understanding of the term "open" [24]. The principles of open innovation are thus perceived to be closely related to the participatory approach of governance [25]. In case of public sector, open innovation have the potential to co-create public policy and services that are desired by the public. Citizens and governments collaborate and share the responsibility for resources, decision making, and the management of public services; this essentially discards the notion that the responsibility of designing and providing public services lies with only governments [21]. Citizen participation is now a core component of the process. Egovernment services are evolving and inclusiveness of citizens is a necessary prerequisite for improving the public services [26-27].

\subsection{Meta-Synthesis}

Synthesis of knowledge is important considering that it is the accumulation of knowledge from the research evidence of the extant studies on which the foundation of science rests [28-29]. Meta-studies (i.e., the analysis of the analysis) being grounded in the evolutionary process of knowledge building thus can offer significant insights into a phenomenon [14]. Broadly, the array of synthesis activities in organizational and management research can be classified into (1) aggregation synthesis; (2) interpretation synthesis; and (3) translation synthesis, with each having distinct ways of approaching a synthesis of knowledge [14].

Aggregation synthesis is grounded in positivist and quantitative tradition. A metaanalysis provides an understanding of research synthesis as aggregation [52], and is viewed as an effective and efficient approach of testing a theory or establishing a predictive theory $[28,30,31]$. For a meta-analysis, prior study results become the primary data. The empirical findings that are dispersed across time and publications are then statistically synthesized [32, 34-37]. Against this, some researchers follow an inductive form of knowledge synthesis that goes beyond the deductive logic of classical positivism and provides interpretations across the existing qualitative studies. As opposed to the quantitative aggregation, the purpose of which is to generate prediction, interpretation synthesis refers to the accumulation of primary evidence for producing interpretive explanation. The synthesis involves the extraction and analysis of insights generated within the primary studies. Through this process, it seeks to identify categories and patterns that emerge across the studies with an attempt to preserve the integrity of original studies [14]. The goal is to make a theoretical contribution by taking into account the local contexts [38]. Lastly, the research synthesis as translation is rooted in a constructivist paradigm and especially applied in medical science, health care, or social and political policy [39]. Within this perspective, synthesis of knowledge is contingent on data that are viewed as "constructed entities" and the goal is to develop "the informed and meaningful reconstruction of how the study's participants constructed their own understandings" $[14$, p. 526].

In case of interpretation synthesis, the data, analysis, and the consequent insights are considered as separate entities. And, this qualitative evidence of the case studies are collected and subsequently synthesized to build a theory. In this study, the objective is 
to perform a synthesis without violating the essence and integrity of the qualitative case study research. Therefore, we contend that it would be reasonable to follow the perspective of interpretation synthesis to best carry out a meta-synthesis.

\subsection{Meta-Synthesis of Qualitative Case Studies}

A case study approach for a research is useful to answer the questions of why or how [38]. Case studies demonstrate how particular practices are developed and carried out in particular organizations, and contribute to theory building [40]. Further, qualitative case studies create the scope of studying the research question in depth that could lead to unexpected, but interesting findings, which can form the basis for hypotheses to be empirically examined in future research [38]. Within the broader array of case study research, there directions are apparent ranging from inductive, interpretive case studies to more indicative, comparative case study research used to build theory in a post-positivist fashion [38, 41-43]. A case study research usually focuses on a specific phenomenon, and researchers conducting the case study research seek to understand it completely. Rather than controlling variables the case study researchers observe all the variables, study the interactions among variables, and explore the contextual conditions pertinent to the phenomenon under study [38, 41-42]. Case study research has the ability to include a variety of data sources and methodologies that produce in-depth qualitative findings in specific contexts [38, 44].

A meta-synthesis is defined as "an exploratory, inductive research design to synthesize primary qualitative case studies for the purpose of making contributions beyond those achieved in the original studies" [14, p. 527]. Essentially, it is a meta-study because it involves the accumulation of the evidence from prior case studies, and it extracts, analyzes, and synthesizes the prior evidence. Therefore, a meta-synthesis does not advocate the reuse of the original primary data collected by the case researchers [14]. Instead, a meta-synthesis is conducted on the insights constructed by the original researchers of the primary studies with respect to their own understanding and interpretation.

\section{$3 \quad$ Research Design}

\subsection{Framing the Research Question}

This study aims at exploring the process of co-creation of e-government services and understanding the role of the government in facilitating citizen participation. Consistent with our research objective, we choose to frame our research questions as: How does the government facilitate the co-creation of e-government services? How does the government motivate citizens to participate in the development of e-government services? 


\subsection{Locating Relevant Research}

The important step in our study was to identify the bodies of research that are relevant for our meta-synthesis interest. Given the volume of studies in the field of egovernment, it was challenging to formulate search keywords pertaining to our research question. As some terms can be expressed in several forms, we decided to combine different keywords related to e-government, participation, and qualitative case study methodology. Finally, we based the search in Scopus and ABI/INFORM digital libraries using keywords ("electronic government" OR "e government" OR "egovernment" OR "digital government" OR "open government" OR "public eservice") AND ("participation" OR "engage" OR "collaborative" OR "open data" OR "involvement" OR "participatory" OR "co creation" OR "co production" OR "co operative" OR "co design") AND ("qualitative" OR "case" OR "interview" OR "focus group"). The first set of keywords about e-government was used as a selection criterion in the Title of the articles and other keywords were used as a selection criterion in topic Title, Keywords, and Abstract. This yielded a total of 319 studies published in journals and conference proceedings between January 2001 and March 2019.

Table 1. Summary of the selected articles

\begin{tabular}{|c|c|c|}
\hline Studies & Description & Country \\
\hline $\begin{array}{l}\text { Chatwin and Arku } \\
\text { [13] }\end{array}$ & $\begin{array}{l}\text { Explores the motivation, capabilities and } \\
\text { constraints, and the influence of the institutional } \\
\text { environment on the co-creation of an open } \\
\text { government action plan }\end{array}$ & Ghana \\
\hline $\begin{array}{l}\text { Gascó-Hernández } \\
\text { et al. [45] }\end{array}$ & $\begin{array}{l}\text { Discusses how the training interventions can } \\
\text { increase awareness among citizens, improve users } \\
\text { skills, and potentially engage them in the open } \\
\text { government }\end{array}$ & $\begin{array}{l}\text { Spain, Italy, } \\
\text { and USA }\end{array}$ \\
\hline Axelsson et al. [33] & $\begin{array}{l}\text { Discusses the importance of citizen participation } \\
\text { and involvement in developing public e-services }\end{array}$ & Sweden \\
\hline Nam [46] & $\begin{array}{l}\text { Performs a SWOT analysis to understand the } \\
\text { challenges around open government and } \\
\text { meaningful civic participation }\end{array}$ & Korea \\
\hline $\begin{array}{l}\text { Pilemalm et al. } \\
\text { [48] }\end{array}$ & $\begin{array}{l}\text { Explores inter-organizational and cross-sector } \\
\text { collaborations for participative development of e- } \\
\text { government systems and analyses the challenges }\end{array}$ & Sweden \\
\hline $\begin{array}{l}\text { Olphert and } \\
\text { Damodaran [3] }\end{array}$ & $\begin{array}{l}\text { Focuses on socio-technical and participatory } \\
\text { approach to the development of e-government } \\
\text { systems, and explores the enabling conditions and } \\
\text { benefits of such participatory approach }\end{array}$ & $\begin{array}{l}\text { United } \\
\text { Kingdom }\end{array}$ \\
\hline Chan and Pan [47] & $\begin{array}{l}\text { Focuses on how to identify and engage the relevant } \\
\text { stakeholders in e-government implementation }\end{array}$ & Singapore \\
\hline
\end{tabular}




\begin{tabular}{lll}
$\begin{array}{l}\text { Oostveen and } \\
\text { Besselaar [49] }\end{array}$ & $\begin{array}{l}\text { Applies participatory design principles to involve } \\
\text { users in the design of infrastructural system } \\
\text { prototype }\end{array}$ & Europe \\
McBride et al. [7] & $\begin{array}{l}\text { Explores institutional dimensions that can facilitate } \\
\text { open government and citizen participation }\end{array}$ & USA \\
Safarov [11] & $\begin{array}{l}\text { Discusses factors that are important for driving the } \\
\text { co-creation of open government data driven public }\end{array}$ & $\begin{array}{l}\text { Sweden, and } \\
\text { services }\end{array}$ \\
\hline
\end{tabular}

To find the relevant studies amongst these 319 studies, we first went through their abstracts to have an overview of the studies. Most articles except 48 were identified as false positives and excluded due to the lack of relevance. These 48 articles were then thoroughly studied to assess whether they pertain to our research questions. Finally, the articles that were found to discuss the co-creation and open government phenomenon from citizens' perspective, or the articles that did not employ qualitative case study research, or case studies that were quantitative in nature were excluded. Therefore, within the subset of 48 articles, we finally identified 10 articles for our meta-synthesis. A brief description of these articles is presented in Table 1 .

\section{$4 \quad$ Analysis}

\subsection{Analysis on a Case-Specific Level}

Hoon suggested that before embarking on the meta-synthesis, an analysis has to be carried out on a case-specific level [14]. That is, each case study under synthesis has to be explored individually as a first step towards executing the meta-synthesis. As the current study intends to understand how citizens can be engaged in the co-creation of e-government services, we explored each case study in terms of the factors that drive the co-creation. At the same time, to capture the role of the government in facilitating citizen participation, we specifically identified factors that are important for the government to enable the phenomenon of co-creation and investigated the process of achieving such collaboration. As suggested by Hoon [14], and Miles and Huberman [44], we developed a network by establishing relationships among the relevant factors for each case study. Such technique helps to map each case into a case-specific network of variables that could generate the underlying theme for the phenomenon of interest. For instance, one case-specific network suggests that "intrinsic motivation" of the government influences the way governments facilitate the co-creation of e-government.

\subsection{Synthesis on a Cross-Study Level}

As the next step towards carrying out the meta-synthesis, we moved from case-specific level analysis to cross-study level analysis. The case-specific networks developed in the previous step are the foundation to further understand how the studies under synthesis are connected or different [14]. Thus, the factors that were identified in each of the case studies and represented through the case-specific network were now 
compared and assessed for their commonalities across studies. To elaborate, we observed (1) how and which components of the case-specific networks were similar across the studies under synthesis; (2) how the factors were different across the casespecific networks; (3) if the relationships between the factors could hold across the studies; and (4) if new set of relationships can be formed by merging the case-specific networks. This process resulted into an integrated network called as meta-causal network that established relationships among the broad factors identified throughout the studies under synthesis. The meta-causal network shown in Figure 1 provides a process view of the co-creation of e-government systems from governments' perspective.

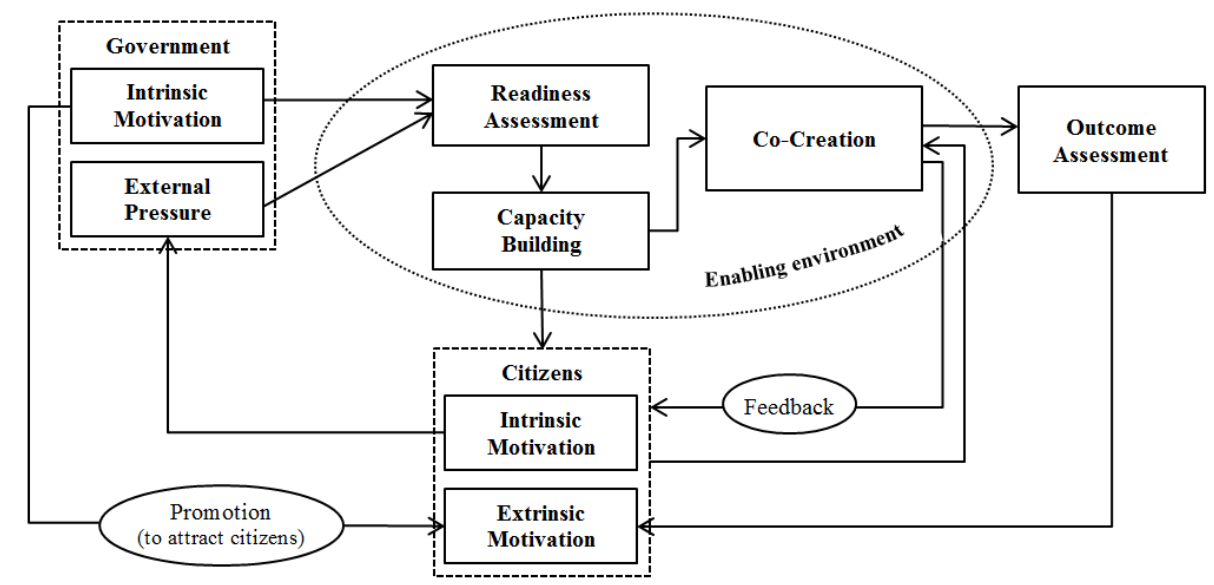

Fig. 1. The process view of the co-creation of e-government services

\section{Discussion}

This study, through a meta-synthesis of qualitative case studies, provides some crucial insights into the process of co-creation in e-government services. Specifically, our aim was to investigate the co-creation from governments' perspective whereby we explored (1) governments' perception of the co-creation, and (2) how they facilitate citizen participation in the co-creation of e-government services. The meta-causal network (Figure 1) that emerged from the meta-synthesis of the selected case studies renders a holistic view in that direction. It represents the process view of the co-creation of egovernment services that delineates how the co-creation of e-government services is initiated and facilitated.

The co-creation of e-government services or the participatory approach to the development of e-government can be initiated by the government or the citizens. We first describe the process of co-creation when the government becomes pioneer. In such instances, usually the government could be internally motivated to engage citizens while developing public services. It could be the commitment towards enhancing public value and serving the communities, and/or the willingness to rebuild trust between the government and its constituents that could motivate the government to take the 
initiative, as discussed in the case study by [13]. Further, the perceived benefits of the co-creation can also incentivize the government internally to take up the participatory approach. Internal motivation of the government thus has been observed as a main driver of co-creation $[7,13]$.

Once motivated, the government may embark on assessing its readiness. This is a crucial step that eventually determines the success of the government initiatives in most cases. Readiness assessment includes the assessment of technological, financial, and human resources. Most case studies under the synthesis discussed the importance of technological infrastructure in influencing the co-creation phenomenon [7, 13, 45]. If the technological infrastructure is weak in a locality, and the government portal is not accessible and lacks user-centred design and interactive functionalities, it is highly unlikely that it would encourage the citizens to participate in the e-government service development and delivery $[3,45]$. Further, the financial resources are also necessary for the co-creation as the implementation of systems, the development of new services, and the organization of the whole process often require huge financial support $[7,13]$. Human resources include the ability of the public managers and employees, more specifically their skills and knowledge of designing, implementing, and managing an e-government initiative [45]. Not only are the technical and managerial skills and experience of public employees important but the technical skills of citizens also matter for the co-creation. This is closely linked to the next tenet of the process view of cocreation, namely, capacity building.

The importance of capacity building is cited in most of the case studies under synthesis $[3,7,13,45-46]$. Capacity building for the government encompasses several facets ranging from developing technical skills and knowledge, to developing communication skills to engage citizens, to building innovative leadership. An innovative leader can look for opportunities and have strategic action plan for motivating and engaging citizens. Similarly, proper communication with citizens can motivate them to participate in developing e-government services. For that, many researchers emphasized the requirement of citizen communication system [13]. Case studies suggest the need for proper training interventions for the public employees to address any gap in their capability [13, 45]. Capacity building also indicates the need for improving skills and knowledge of citizens for the success of e-government.

The process view of co-creation as presented in Figure 1 shows that once the government assesses its resources and capability required for developing e-services and engaging citizens, the government can participate in the co-creation of e-government services. Nonetheless, before that, it is necessary that the government makes citizens aware of the e-government services that require participation from citizens. Analysing its importance, the need for public awareness activities is discussed in many of the case studies. The government has to inform citizens, through town hall meetings or radio shows or workshops, the utility of the particular e-service, the values of participating in e-government, and the existence of incentives, if any [11]. Public awareness activities become more significant, especially when the citizens do not initiate the process of co-creation. The goal is to convince citizens and sensitize them so that they become motivated to participate in e-government [45].

While interacting with citizens, the government has to understand the user need at the same time. Many a time, when governments take the initiative, they opt for implementing an e-service that they feel comfortable and convenient without assessing 
the citizen demand of solving real problems. Heeks [50, p. 162] indicates this as "an opportunity which could be seized" in opposite to "a problem that needs to be solved". The decision has to be driven by the citizen demand or need [33]. The lack of citizen focus becomes detrimental for the success of e-government.

We discussed so far the process of co-creation that was initiated by the government. As stated previously, the citizens may also initiate the process. When there is increased awareness from citizens about their rights and responsibilities, they have particular demand for enhancing public value, and they are intrinsically motivated, then they could cast pressure on the government for creating e-services [13]. Such intrinsic motivation of citizens may act as the external pressure for the government in the process of co-creation of e-government services. Once both the stakeholders- the government and the citizenry are motivated either intrinsically or extrinsically, the phenomenon of co-creation takes place. Further, to have sustained citizen engagement, a feedback mechanism could be beneficial whereby the citizens can receive constructive feedback on their participation [47]. It is worthy to note that it may not always be possible for the government to directly engage citizens in every egovernment service development. The role of intermediary becomes significant in that case, indicating the need for stakeholder identification and management by the government [49].

In addition, it is to be noted that the enabling environment has significant role in facilitating the co-creation. The institutional environment such as the political environment and the legislative acts [11], and the economic factors [45] could affect the availability of technological, financial, and human resources, and determine the readiness and the ability of the government.

This meta-synthesis study contributes to the literature on the co-creation and egovernment by providing a holistic understanding of the process of co-creation of egovernment services. We integrate the co-creation process initiated by the government with that initiated by the citizens. We contend that governments' perception of the cocreation largely determines the way they conduct. If governments realize the benefits of engaging citizens in the e-government service development, they are motivated to initiate and participate in such participatory development process. Apart from the perceived benefits, their commitment towards serving the communities plays a major role in facilitating the co-creation. Further, to engage citizens, we discuss the mechanisms that are emerged from the case studies under synthesis. In particular, we emphasize the need for promoting e-government initiatives, developing public awareness activities, facilitating training interventions, developing effective communication systems, building innovative leadership, and providing technological and related resources to citizens. In essence, the proposed process view of co-creation would enable researchers, practitioners, and policy makers to develop insights into the important parameters enabling the co-creation of e-government services for effective and efficient public service delivery.

The major limitation of this study is that it relies on published articles and conference proceedings. In an ideal scenario, any synthesis has to be exhaustive by including maximum number of eligible literature [30, 51]. In this meta-synthesis, we discarded dissertations and unpublished research studies. Nevertheless, this increased the 
scientific rigor of the meta-synthesis considering the acceptance of peer-reviewed publications.

\section{Concluding Remarks}

The effective and efficient delivery of public services is largely dependent on citizen participation for co-creating e-government services. Nevertheless, minimal participation of citizens is witnessed in the development and delivery of e-government services. Realizing the importance of engaging citizens to facilitate the co-creation, this study entails the role and the perceptions of the government through a meta-synthesis of qualitative case studies. A process view of the co-creation of e-government services is proposed to delineate how governments can facilitate citizen participation in the cocreation of e-government services to enhance the public value. We believe that this process view would enhance the understanding of researchers, practitioners, and policy makers about the process of co-creation in the context of e-government, and encourage future empirical research.

\section{References}

1. Mumford, E.: Designing human systems for new technology: The ETHICS method. Manchester Business School, Manchester (1983).

2. Mumford, E.: Participation in systems design - What can it offer? In Shackel, B., Richardson, S. (eds.) Human Factors for Informatics Usability, pp. 267-290. Cambridge University Press, Cambridge (1991).

3. Olphert, W., Damodaran, L.: Citizen participation and engagement in the design of egovernment services: The missing link in effective ICT design and delivery. Journal of the Association for Information Systems 8(9), 491-507 (2007).

4. Osborne, S., Radnor, Z., Strokosch, K.: Co-production and the co-creation of value in public services: A suitable case for treatment? Public Management Review 18(5), 639-653 (2016).

5. Cordella, A., Paletti, A.: Value creation, ICT, and co-production in public sector: Bureaucracy, opensourcing and crowdsourcing. In: Proceedings of the 18th Annual International Conference on Digital Government Research, pp. 185-194. ACM, Staten Island, NY, USA (2017).

6. Uppström, E., Lönn, C.-M.: Explaining value co-creation and co-destruction in egovernment using boundary object theory. Government Information Quarterly 34(3), 406420 (2017).

7. McBride, K., Aavik, G., Toots, M., Kalvet, T., Krimmer, R.: How does open government data driven co-creation occur? Six factors and a 'perfect storm'; insights from Chicago's food inspection forecasting model. Government Information Quarterly 36(1), 88-97 (2019).

8. Toots, M., McBride, K., Kalvet, T., Krimmer, R.: Open data as enabler of public service cocreation: Exploring the drivers and barriers. In: Proceedings of the International conference for e-democracy and open government, pp. 102-112. Krems, Austria (2017).

9. Voorberg, W., Bekkers, V., Tummers, L. A systematic review of co-creation and coproduction: Embarking on the social innovation journey. Public Management Review 17(9), 1333-1357 (2015). 
10. Safarov, I., Meijer, A., Grimmelikhuijsen, S.: Utilization of open government data: A systematic literature review of types, conditions, effects and users. Information Polity 22(1), 1-24 (2017).

11. Safarov, I.: Institutional dimensions of open government data implementation: Evidence from the Netherlands, Sweden, and the UK. Public Performance \& Management Review 124 (2018).

12. Styrin, E., Luna-Reyes, L. F., Harrison, T. M.: Open data ecosystems: An international comparison. Transforming Government: People, Process and Policy 11(1), 132-156 (2017).

13. Chatwin, M., Arku, G.: Co-creating an open government action plan: The case of SekondiTakoradi metropolitan assembly, Ghana. Growth and Change 49(2), 374-393 (2018).

14. Hoon, C.: Meta-synthesis of qualitative case studies: An approach to theory building. Organizational Research Methods 16(4), 522-556 (2013).

15. Bryson, J., Crosby, B., Bloomberg, L.: Public value governance: Moving beyond traditional public administration and the new public management. Public Administration Review 74(4), 445-456 (2014).

16. Bryson, J., Sancino, A., Benington, J., Sørensen, E.: Towards a multi-actor theory of public value co-creation. Public Management Review 19(5), 640-654 (2017).

17. Moore, M.: Public value as the focus of strategy. Australian Journal of Public Administration 53(3), 296-303 (1994).

18. Stoker, G.: Public value management. The American Review of Public Administration 36(1), 41-57 (2006).

19. Ostrom, E.: Metropolitan reform: Propositions derived from two traditions. Social Science Quarterly 474-493 (1972).

20. Osborne, S.: From public service-dominant logic to public service logic: Are public service organizations capable of co-production and value co-creation? Public Management Review 20(2), 225-231 (2018).

21. Osborne, S., Strokosch, K.: It takes two to tango? Understanding the co-production of public services by integrating the services management and public administration perspectives. British Journal of Management 24, 31-47 (2013).

22. Möslein, K.: Open innovation: Actors, tools and tensions. In: Huff, A., Möslein, K. Reichwald, R. (eds.) Leading open innovation, pp. 69-86. MIT Press, Cambridge, MA (2013).

23. Seltzer, E., Mahmoudi, D.: Citizen participation, open innovation, and crowdsourcing: Challenges and opportunities for planning. Journal of Planning Literature, 3-18 (2013).

24. Yu, H., Robinson, D.: The new ambiguity of open government. UCLA Law Review Discourse, 180-208 (2012).

25. Baka, V.: Co-creating an open platform at the local governance level: How openness is enacted in Zambia. Government Information Quarterly 34(1), 140-152 (2017).

26. Cornwall, A.: Democratising engagement what the UK can learn from international experience. Demos, London (2008).

27. Griffiths, S., Foley, B., Prendergast, J.: Assertive citizens: New relationships in the public services. Social Market Foundation, London (2009).

28. Hunt, M.: How science takes stock: The story of meta-analysis. Russell Sage, New York (1997).

29. Hunter, J. E., Schmidt, F., Jackson, G.: Meta-analysis: Cumulating research findings across studies. Sage, Beverly Hills, CA (1982).

30. Aytug, Z. G., Rothstein, H. R., Zhou, W., Kern, M. C.: Revealed or concealed? Transparency of procedures, decisions, and judgment calls in meta-analyses. Organizational Research Methods 15, 103-133 (2012). 
31. Cooper, H.: Research synthesis and meta-analysis: A step-by-step approach. 4th edn. Sage, Thousand Oaks, CA (2010).

32. Aguinis, H., Pierce, C. A., Bosco, F. A., Dalton, D. R., Dalton, C. M.: Debunking myths and urban legends about meta-analysis. Organizational Research Methods 14, 306-331 (2011).

33. Axelsson, K., Melin, U., Lindgren, I.: Exploring the importance of citizen participation and involvement in e-government projects: Practice, incentives, and organization. Transforming Government: People, Process and Policy 4(4), 299-321 (2010).

34. Carlson, K. D., Ji, F. X.: Citing and building on meta-analytic findings: A review and recommendations. Organizational Research Methods 14, 696-717 (2011).

35. Dalton, D. R., Dalton, C. M.: Meta-analyses: Some very good steps toward a bit longer journey. Organizational Research Methods 11, 127-147 (2008).

36. Glass, G. V.: Integrating findings: The meta-analysis of research. Review of Research in Education 5, 351-379 (1977).

37. Schmidt, F. L.: Meta-analysis: A constantly evolving research integration tool. Organizational Research Methods 11, 96-113 (2008).

38. Yin, R.: Case study research: Design and methods. 3rd edn. Sage, Thousand Oaks, CA (2009).

39. Tranfield, D., Denyer, D., Smart, P.: Towards a methodology for developing evidenceinformed management knowledge by means of systematic review. British Journal of Management 14(3), 207-222 (2003).

40. Scapens, R. W.: Researching management accounting practice: The role of case study methods. The British Accounting Review 22(3), 259-281 (1990).

41. Eisenhardt, K. M.: Building theories from case study research. Academy of Management Review 14, 532-550 (1989).

42. Eisenhardt, K. M., Graebner, M. E.: Theory building from cases: Opportunities and challenges. Academy of Management Journal 50, 25-32 (2007).

43. Sigglekow, N.: Persuasion with case studies. Academy of Management Journal 50, 20-24 (2007).

44. Miles, M. B., Huberman, A. M.: Qualitative data analysis: An expanded sourcebook. 2nd edn. Sage, Thousand Oaks, CA (1994).

45. Gascó-Hernández, M., Martin, E. G., Reggi, L., Pyo, S., Luna-Reyes, L. F.: Promoting the use of open government data: Cases of training and engagement. Government Information Quarterly 35, 233-242 (2018).

46. Nam, T.: Challenges and concerns of open government: A case of Government 3.0 in Korea. Social Science Computer Review 33(5), 556-570 (2015).

47. Chan, C. M., Pan, S. L.: User engagement in e-government systems implementation: A comparative case study of two Singaporean e-government initiatives. Journal of Strategic Information Systems 17, 124-139 (2008).

48. Pilemalm, S., Lindgren, I., Ramsell, E.: Emerging forms of inter-organizational and crosssector collaborations in e-government initiatives: Implications for participative development of information systems. Transforming Government: People, Process and Policy 10(4), 605636 (2016).

49. Oostveen, A.-M., Besselaar, P. V.: From small scale to large scale user participation: A case study of participatory design in e-government systems.In: Proceedings of the eighth conference on Participatory Design Artful integration interweaving media materials and practices PDC 04, pp. 173-182. Toronto, Canada (2004).

50. Heeks, R.: Implementing and managing eGovernment: An international text. Sage, London (2006). 
51. Kisamore, J., Brannick, M. T.: An illustration of the consequences of meta-analysis model choice. Organizational Research Methods 11, 35-53 (2008).

52. Rousseau, D., Manning, J., Denyer, D.: Evidence in management and organizational science: Assembling the field's full weight to scientific knowledge through synthesis. Academy of Management Annals 2, 475-515 (2008). 